\title{
Thermal damage of internal thoracic artery and ultra high radiofrequency
}

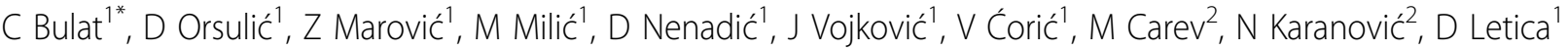 \\ From 23rd World Congress of the World Society of Cardio-Thoracic Surgeons \\ Split, Croatia. 12-15 September 2013
}

\section{Background}

The gold standard in left anterior descending branch coronary artery surgery is performing an internal thoracic artery (ITA) bypass. Skeletonization techniques of harvesting have been suggested for maximizing the utility of ITA. It still remains questionable what is the best method for ITA harvesting in a skeletonized fashion according to structural integrity of artery, as a risk factor of early and late graft failure. The purpose of this study was to determine the impact of the ultra-high radiofrequency energy $(2.0-4.0 \mathrm{MHz})$ used for ITA harvesting on arterial structural integrity, in particular on the endothelial layer.

\section{Methods}

Seventy-four ITA specimens were divided into two groups depending on device used for harvesting (radiofrequency-knife (RF) or electrocauter (EC)). Thermal damage on arterial structural integrity was measured using light microscope, morphometric imaging analysis and immunohistochemical methods.

\section{Results}

Thermal damage of endothelium was 2.8 times higher in EC than in RF group ( $\mathrm{p}=0.041)$ and 5 times higher in patients older than 66 years of age $(\mathrm{p}=0.002)$. Extent of endothelial damage (graded from 0 to 3 ) was significantly higher in EC group ( $\mathrm{p}=0.03)$.

\section{Conclusion}

The endothelial damage was more often in EC than in RF group as in the patients older than 66 years of age. Demonstrated results suggest that the radiosurgery in

\footnotetext{
* Correspondence: cristijan.bulat@zg.t-com.hr

${ }^{1}$ Department of Cardiac Surgery, University Hospital Centre Split, Split, Croatia

Full list of author information is available at the end of the article
}

comparison to conventional electrocautery could reduce thermal damage to the endothelial layer of ITA, compared to the conventional electrocautery and potentially optimize the quality of ITA bypass grafts.

\section{Authors' details}

'Department of Cardiac Surgery, University Hospital Centre Split, Split, Croatia. ${ }^{2}$ Department of Anesthesiology, University Hospital Centre Split, Split, Croatia

Published: 11 September 2013

doi:10.1186/1749-8090-8-S1-P113

Cite this article as: Bulat et al:: Thermal damage of internal thoracic artery and ultra high radiofrequency. Journal of Cardiothoracic Surgery 2013 8(Suppl 1):P113.
Submit your next manuscript to BioMed Central and take full advantage of:

- Convenient online submission

- Thorough peer review

- No space constraints or color figure charges

- Immediate publication on acceptance

- Inclusion in PubMed, CAS, Scopus and Google Scholar

- Research which is freely available for redistribution

Submit your manuscript at www.biomedcentral.com/submit
() Biomed Central

\section{Biomed Central}

(c) 2013 Bulat et al; licensee BioMed Central Ltd. This is an Open Access article distributed under the terms of the Creative Commons Attribution License (http://creativecommons.org/licenses/by/2.0), which permits unrestricted use, distribution, and reproduction in any medium, provided the original work is properly cited. 